\title{
Die Lyapunov-ongelykheid en konveks-inverteerbare keëls
}

\section{Outeurs: \\ Alma Naudé, \\ S ter Horst \\ Affiliasie: \\ Departement Wiskunde en Toegepaste Wiskunde, Noordwes-Universiteit Privaatsak X6001, Potchefstroom, 2520 \\ Korresponderende outeur: A Naudé \\ E-pos: \\ naudealma@gmail.com}

Hoe om hierdie artikel aan te haal:

Alma Naudé, S ter Horst,

Die Lyapunov-ongelyk-

heid en konveks-

inverteerbare keëls,

Suid-Afrikaanse Tydskrif

vir Natuurwetenskap en

Tegnologie 38(1) (2019).

https://doi.org/10.36303/

SATNT.2019.38.1.771

Kopiereg:

C) 2019. Authors.

Licensee: Die SuidAfrikaanse Akademie vir

Wetenskap en Kuns.

Hierdie werk is onder

die Creative Commons

Attribution License

gelisensieer.
The Lyapunov inequality and convex invertible cones: After looking at convex invertible cones (cics) and the Lyapunov inequality, we are now focusing on the relation that exists between the function cic consisting of positive, real, odd rational functions (PRO), and matrix cics, the relation being for a real matrix $\mathrm{B}$ belonging to the cic generated by a real matrix A. There exists at least one $f$ in PRO such that $f(\mathrm{~A})=\mathrm{B}$. This relation was given as a theorem by Cohen and Lewkowicz.

'n Nie-leë deelversameling van 'n vektorruimte word 'n konvekse keël genoem indien die versameling geslote is onder optelling en nie-negatiewe skalering. Vir ' $n$ visuele voorstelling van 'n konvekse keël, dink aan 'n roomyskeël. Dit stel egter 'n baie eenvoudige konvekse keël voor en vir meer ingewikkelde konvekse keëls is 'n visuele voorstelling nie noodwendig moontlik nie. Konvekse keëls, gedefinieer op 'n algebra met 'n eenheidselement, wat geslote is onder die neem van inverses, noem ons konveks-inverteerbare keëls - kortliks skryf ons kiks. Kiks speel onder meer 'n belangrike rol in stelsel- en beheerteorie, vanweë die verband tussen kiks en die Lyapunov-ongelykheid, wat onder andere toegepas word in die studie van die stabiliteit van lineêre stelsels van differensiaalvergelykings. Voorbeelde van kiks kom voor in matriks- en funksie-algebras.

Een voorbeeld van 'n kik wat ons beskou het, is in die algebra van reële, rasionale funksies R. Die algebra $\mathrm{R}$ bestaan dus uit alle funksies $f$ wat uitgedruk kan word as die verhouding van twee reële polinome in 'n komplekse veranderlike, waar inversie gegee word deur involusie $f$ $\rightarrow 1 / f$. Die funksie-kik waarop ons konsentreer, is die kik van positiewe, onewe, reële, rasionale funksies (PRO). Funksies van hierdie aard speel 'n belangrike rol in elektriese ingenieurswese.

Vanweë Lyapunov se stelling, wat aan ons 'n manier bied om meer oor 'n willekeurige matriks A te wete te kom, veral A se eiewaardes, ondersoek ons die Lyapunov-ongelykheid. Ons beperk onsself tot reële matriks-kiks en die reële Lyapunov-ongelykheid wat vir 'n gegewe reële matriks $A$, 'n simmetriese matriks $S$ soek sodat $S A+A^{H} S$ positief semi-definiet is, waar $\mathrm{A}^{\mathrm{H}}$ die Hermitiese getransponeerde van $\mathrm{A}$ is. Die versameling van alle matrikse $\mathrm{S}$ wat die Lyapunov-ongelykheid vir A bevredig, vorm 'n matriks-kik. Daar ontstaan 'n ordening op die algebra van vierkantige matrikse, bekend as die Lyapunov-orde, as ons stel dat 'n matriks A deur 'n matriks B gedomineer word wanneer die oplossings van die Lyapunov-ongelykheid vir A ook oplossings van die Lyapunov-ongelykheid vir B is. Die versameling van alle matrikse $\mathrm{B}$ wat A domineer in die Lyapunov-orde vorm ook 'n matriks-kik.

Cohen en Lewkowicz $(2007 ; 2009)$ wys op die volgende verband tussen matriks-kiks en die funksie-kik PRO: 'n Reële matriks B sal aan die kik behoort wat voortgebring word deur 'n reële matriks $A$ as, en slegs as, daar' $n f$ in die kik PRO bestaan sodat $B=f(A)$. Hierdie resultaat kan gesien word as 'n interpolasiestelling. Dit is egter nie eenvoudig om te bepaal of $B$ aan die kik behoort wat deur A voortgebring word nie. Onder sekere voorwaardes op A en B wys Cohen en Lewkowicz (2009) hoe die Lyapunov-orde gebruik kan word om te bepaal wanneer $\mathrm{B}$ in die kik voortgebring deur $\mathrm{A}$ is.

\section{Literatuurverwysings}

Cohen, N. \& Lewkowicz, I., 2007, 'Convex invertible cones and positive real analytic functions', Linear Algebra Appl., 425, $797-813$.

Cohen, N. \& Lewkowicz, I., 2009, 'The Lyapunov order for real matrices', Linear Algebra Appl., 430, 1849-1866.

Nota: 'n Seleksie van referaatopsommings: Studentesimposium in die Natuurwetenskappe, 25-26 Oktober 2018, SA Akademiegebou, Pretoria, Suid-Afrika. Gasredakteurs: Prof Rudi Pretorius (Departement Geografie, Universiteit van Suid-Afrika); Prof Chris Swanepoel (Departement Besluitkunde, Universiteit van Suid-Afrika); Me Andrea Lombard (Departement Geografie, Universiteit van Suid-Afrika) 